\title{
FLT3 Gene Amplification
}

National Cancer Institute

\section{Source}

National Cancer Institute. FLT3 Gene Amplification. NCI Thesaurus. Code C150624.

A molecular genetic abnormality indicating the presence of multiple copies of the FLT3 gene. 